\title{
A szíriai menekültválság Libanonban ${ }^{1}$
}

\begin{abstract}
2011-es kezdete óta a szíriai konfliktus a 21. század egyik legnagyobb humanitárius katasztrófáját generálta, nevezetesen a szíriai menekültválságot, amely elsősorban Szíria közvetlen szomszédait érintette. Ám Törökországtól és Jordániától eltéröen Libanont mérete, társadalmi és vallási sajátosságai különleges esettanulmánnyá teszik. Söt, a körülbelül 1,5 millió menekülttel a területén gyakorlatilag Libanonban van a lakosság számához képest a világon a legtöbb menekült. A tanulmány célja bemutatni a menekültek libanoni jelenlétének valamennyi aspektusát és az azzal összefüggő problémákat. Az első rész több nézőpontból igyekszik ismertetni az elhúzódó menekültválságot. Ezt követően bemutatja az ország különböző szereplőinek a menekültkérdéssel kapcsolatos helyi és nemzetközi intézkedéseit, rámutatva, hogy azok hátterében sokszor a törékeny libanoni szektariánus társadalmi egyensúly megőrzése áll. Végül pedig a szerző libanoni terepmunkája során végzett megfigyelései és tapasztalatai alapján ad képet a menekültek mindennapjairól.
\end{abstract}

Kulcsszavak: Közel-Kelet, szíriai polgárháború, Libanon, menekültválság, migráció

\section{Elias Dahrouge: The Syrian refugee crisis in Lebanon}

Since its beginning in 2011, the Syrian conflict generated one of the greatest humanitarian catastrophes of the 21st century, namely the Syrian refugee crisis. This crisis mainly affected Syria's direct neighbours. However, unlike Turkey or Jordan, the case of Lebanon is peculiar - due to its size and unique socio-religious character-, and it is worth a case study. In fact, with around 1.5 million refugees, the country has the highest rate of refugees per capita in the world. This study aims to present all the aspects and issues related to the refugees' presence in this country. In a first part, this article presents the multiple aspects of this long-lasting crisis. Then it shows the local and international actions undertaken by the country's different actors, and investigates how their motives relate to the fragility of the Lebanese sectarian demographic balance. Finally, it pictures the daily life of the refugees, reflecting on the empirical observations made by the author during his fieldwork trips to Lebanon.

Keywords: Middle East, Syrian civil war, Lebanon, refugee crisis, migration

\section{Bevezetés $^{2}$}

A 2011 óta tartó szíriai polgárháborúnak a fontos katonai, stratégiai és politikai aspektusai mellett súlyos humanitárius következményei is vannak. A halálos áldozatok és az eltűntek magas száma mellett az egyik legföbb probléma a menekültek kérdése. A polgárháború

\footnotetext{
1 Jelen publikáció a BCE EFOP-3.6.3-VEKOP-16-2017-00007, „Tehetségből fiatal kutató” - A kutatói életpályát támogató tevékenységek a felsőoktatásban címü projekt keretében készült.

2 Ezúton szeretnék köszönetet mondani Selján Péter kollégámnak a tanulmány magyar nyelvi ellenőrzéséért.
} 
előtti Szíria közel 22 milliós ${ }^{3}$ lakosságának több mint a fele vagy életét vesztette a harcokban, vagy lakóhelye elhagyására kényszerült, és ezért ma már belföldi menekültnek számít, vagy elsősorban szomszédos, másodsorban a távoli országokban lelt menedékre. Ezzel a szíriai humanitárius katasztrófa a 21. század eddigi egyik legnagyobb emberi tragédiájának tekinthető. Egyes adatok szerint az otthonaikat elhagyni kényszerült belső menekültek száma meghaladja a 6 millió főt, ${ }^{4}$ miközben további 7 millióra becsülhető azoknak a száma, akik végül elhagyták az országot. Az óriási menekültáradat a szomszédos országokat érinti leginkább, elsősorban Törökországot (3,7 millió menekülttel $\left.{ }^{5}\right)$, Libanont (1,5 millió menekülttel $\left.{ }^{6}\right)$ és Jordániát $\left(1,2\right.$ millió menekülttel $\left.{ }^{7}\right)$. A fennmaradó másfél millió pedig Irakban és Egyiptomban, valamint kisebb számban európai és más nyugati országokban talált menedéket magának. ${ }^{8}$

Miközben Törökországban van a legtöbb menekült világszerte, Libanon helyzete a menekültkérdés szempontjából azért is különösen érdekes, mert a lakosság számához viszonyítva a cédrusok országában a legmagasabb, $30 \%$-os a menekültek aránya. ${ }^{9}$ Az ENSZ adatai szerint minden hatodik libanoni állampolgárra jut egy menekült, miközben más szervek szerint ez az arány akár 3: 1-hez is lehet. ${ }^{10}$ Megjegyzendő, hogy ezek az adatok is csupán becslések, mivel a számok pontosítását nagymértékben megnehezíti, hogy Libanonban 1932 óta nem került sor hivatalos állami népszámlálásra, ráadásul a menekülteknek is csak egy része került be az ENSZ rendszerébe regisztrált menekültként, így a különböző adatsorok eltérő számokat mutatnak. A menekültek megjelenése viszont nem ismeretlen jelenség Libanon számára, hiszen 1948 óta már közel félmillió Palesztin menekült él a Libanoni Köztársaság területén. E populáció száma hozzáadódik a szíriai menekültek számához, ezzel is rontva a fentiekben már említett arányokat. Mindemellett Libanon vallási sokszínüsége miatt is különleges országnak számít, ezért is tartjuk nagyon relevánsnak az ott élő szíriai menekültek helyzetének vizsgálatát, mivel egy ilyen komplex társadalmi berendezkedésben bekövetkező bármilyen komolyabb demográfiai változás nagy hatással lehet az egyes vallások között korábban kialakult, igen érzékeny egyensúlyra, amely pedig a politikai status quót is megváltoztathatja.

A tanulmány első része bemutatja a szíriai polgárháború Libanont leginkább érintő aspektusát, azaz a Libanonban tartózkodó szíriai menekültek helyzetét számokkal és más adatokkal alátámasztva. Ezt követően röviden elemzi a libanoni államnak a menekültválság kihívásaira adott válaszait és az azokból adódó problémákat. A harmadik részben a szerző által a helyszínen végzett kutatómunka eredményeit összegző beszámoló keretében ismerhetik meg az olvasók a szíriai menekültek mindennapi problémáit.

Syria’s drained population: Syria’s depleted and war-torn population, [online], 2015. 09. 30. Forrás: economist.com [2019. 11. 19.]

Global Trends: Forced Displacement in 2018, [online], 2019. Forrás: unhcr.org [2019. 11. 19.]

Uo.

Lebanon Fact Sheet, [online], 2019.02. Forrás: unhcr.org [2019. 11. 30.]

Josef Federman - Omar Akour: Trapped in Jordan, Syrian refugees see no way home, [online], 2019. 10. 11. Forrás: apnews.com [2019. 11. 19.]

8 Phillip Connor: Most displaced Syrians are in the Middle East, and about a million are in Europe, [online], 2018. 01. 29. Forrás: pewresearch.org [2019. 11. 19.]

9 Global Trends: Forced Displacement in 2018: i. m.

10 Lebanon Factsheet, [online], 2019. 08. 26. Forrás: ec.europa.eu [2019. 11. 19.] 


\section{A szíriai menekültek Libanonban: húzó- és tolótényezők}

A migrációs folyamatokkal és a menekültek mozgásával foglalkozó tanulmányok egyik gyakran hivatkozott magyarázó elve a „push and pull” migrációs elmélet, azaz a toló és húzó motivációs tényezők elmélete, amely a kiváltó okokra fókuszálva igyekszik magyarázatot adni a migráció jelenségére. ${ }^{11}$ E szerint minden népvándorlásnál azonosíthatók a távozásra ösztönző „tolótényezők” és az egyes célországokba irányuló migrációra sarkalló „húzótényezők” is, amelyek lehetnek gazdasági, biztonsági vagy akár éghajlati problémákra visszavezethető okok is. ${ }^{12}$ Ezek a motivációs tényezők pedig azon szíriai menekültek esetében is azonosíthatók, akik 2011-től, a szíriai polgárháború eszkalálódását követően érkeztek Libanonba. A szíriai menekültek esetében a fö tolótényezők egyértelmüen a biztonság teljes hiánya, a szíriai gazdaság összeomlása, az oktatási rendszer és az egészségügyi ellátórendszer müködésképtelensége, ami gyakorlatilag mind a polgárháború következménye. Ezzel szemben Libanont illetően a húzótényezők között megemlíthető, hogy biztonságos ország, ahol az ENSZ és a térségben aktív civil szervezetek igyekeznek az alapvető szolgáltatásokat és esetleg munkalehetőséget is biztosítani a menekültek számára. Mindemellett Libanon mint célország mellett szól még a kedvező földrajzi elhelyezkedése, azaz könnyü megközelíthetősége, az évszázadokra visszatekintő közös múlt és az abból eredő erős társadalmi-kulturális összefonódottsága is Szíriával.

$\mathrm{Az}$ arab tavasz eseménysorába illeszthető kormányellenes békés tüntetések Szíriában 2011 márciusa és júniusa között eszkalálódtak a kormányerők és a tiltakozók közötti erőszakos összecsapásokká, és miután a rezsimnek nem sikerült a tüntetéseket erőszakkal elfojtania, a rezsim részéről a represszióra tett kísérlet végül fegyveres konfliktusba, polgárháborúba torkollt. Az Aszad-rezsim viszonylag hamar erőszak alkalmazásával próbálta letörni a tüntetéseket, ám a szíriai nép nem hagyta magát, és a tüntetők egy része rövid időn belül felfegyverkezve vette fel a harcot a kormányerőkkel. Az eleinte békésen kezdődő tüntetésekből tehát gyakorlatilag fél éven belül lett fegyveres lázadás, majd elhúzódó polgárháború. A kialakult polgárháborús helyzetet később a regionális és a nemzetközi nagyhatalmak mellett más külső szereplők is igyekeztek kihasználni saját érdekeiknek megfelelően. Ebből kifolyólag, akiknek érdekükben állt a szíriai rezsim megbuktatása, azok elkezdték finanszírozni és felfegyverezni a felkelőket, miközben a rezsim hatalmon maradásában érdekelt szereplők pedig pont fordítva, a kormányerőket kezdték el támogatni. Ennek következtében az eleinte a rezsim mellett kitartó fegyveres erők és az ellenzék szembenállásával kezdődő válságból végül egy katonai intervenciókkal és külső szereplők által támogatott proxyk által vívott, nemzetközivé szélesedett fegyveres konfliktus lett. ${ }^{13}$ A sorban egymást követte az Iszlám Állam terjeszkedése, az orosz katonai beavatkozás és az Iszlám Állam elleni nemzetközi koalíció fellépése. Ez persze súlyos anyagi károk, legfőképpen pedig számtalan emberi áldozat árán valósult meg, ami a 21. század egyik legnagyobb humanitárius

11 Felipe Cuamea Velazquez: Approaches to the study of international migration: a review, Estudios Fronterizos, 1. évf., 2000/1, 137-168. o.

12 An introduction to 'push' and 'pull' factors, [online], Forrás: futurelearn.com [2019. 11. 17.]

13 Emile Hoкауем: Iran, the Gulf States and the Syrian Civil War, Survival: Global Politics and Strategy, 56. évf., 2014/6, 59-86. o. 
válságát eredményezve a szíriai nép millióit kényszerítette menekülésre. A szíriai menekültáradat pedig elsősorban a szomszédos országokat érintette, köztük például Libanont.

A migrációt ösztönző tolótényezők után érdemes megvizsgálni azokat a húzótényezőket, amelyek Libanont vonzó célországgá teszik a szíriai menekültek számára. Talán elsőre nem gondolnánk, de a húzótényezőkből több is akad. Libanon már az események kibontakozásának elején is logikus úticélnak minősült a Szíriából menekülők számára, hisz nemcsak hogy közel van, de számtalan ponton, gazdaságilag és kulturálisan is kötődnek a szírek Libanonhoz. A két ország állampolgáraira például évtizedekig nem vonatkozott semmilyen vízumkényszer, így sokáig egy egyszerü személyazonosító igazolvánnyal is át tudtak kelni a szír-libanoni határon. ${ }^{14}$ Ez a lehetőség csak 2015-ben szünt meg, miután a libanoni hatóságok a korábbi szabályozáson módosítva vízumkényszert vezettek be a szíriai állampolgárokra vonatkozóan, hogy így mérsékeljék a Libanonba érkező menekültek számát. ${ }^{15} \mathrm{~A}$ kijelölt hivatalos határátkelők mellett azonban számtalan illegális csempészútvonal és határátlépési pont áll rendelkezésre azok számára, akik az illegális utat választva érkeznének Libanonba. ${ }^{16}$ Ez részben a szír-libanoni határ képlékenységével vagy inkább tisztázatlanságával magyarázható, hiszen pontosan kijelölt és rögzített hivatalos államhatár hiányában gyakorlatilag nem is végezhető effektív határellenőrzés. ${ }^{17} \mathrm{~A}$ két ország közötti korábbi vízummentesség és a tisztázatlan határviszonyok tehát meghatározó jelentőségü húzótényezőként ösztönözhették a szíriai menekülteket arra, hogy Libanonban keressenek menedéket. Mindemellett megjegyzendő, hogy már a válság 2011-es kialakulása előtt is körülbelül félmillió szír állampolgár tartózkodott Libanonban, többségük ideiglenesen vagy szezonálisan az olcsó munkaerőt igénylő szektorokban dolgozó vendégmunkásként, főleg az építőiparban és a mezőgazdaságban elhelyezkedve. ${ }^{18}$ Ebből pedig egyenesen következett, hogy amikor a szíriai településeiket elérték a fegyveres harcok, ezek a szíriai dolgozók magukhoz csábították először a közvetlen családtagjaikat, majd a közeli és a távoli rokonaikat, végül pedig a korábbi szomszédjaikat is Libanonba. Erre a folyamatra a tanulmány utolsó részében konkrét példákat is ismertetünk majd.

Mindebből három letelepedési minta rajzolódik ki, amelyek hozzájárulhatnak a migrációs folyamatok dinamikájának helyes értelmezéséhez. Az elsődleges letelepedési minta szerint a korábban már Libanonhoz rokoni vagy ismeretségi szinten kötődő menekültek az egész ország területén szétszórva telepedtek le. Mindez pedig számokkal igazolható. A másodlagos letelepedési minta szerint a Libanonhoz sem rokoni szál, sem egyéb kapcsolat által nem kötődő menekültek gyakorlatilag egyszerü határátlépéssel és teljesen szabályozatlan formában telepedtek le az országban. Ez a minta elsősorban a menekültek határmenti településekre és tartományokra koncentrálódó nagyszámú jelenlétére ad némi

\footnotetext{
14 Esperance Gнаnем: Lebanese visa regulations cause more distress for Syrians, [online], 2015. 01. 22. Forrás: al-monitor.com [2019. 10. 11.]

15 Uo.

16 Jamil MouAwAD: Lebanon's border areas in light of the Syrian war: New actors, old marginalisation, [online], 2018. Forrás: European University Institute, Robert Schuman Centre for Advanced Studies, RSCAS/Middle East Directions 2018/03 [2019. 11. 11.]

17 Uo.

18 Lea Bou Khater: Labour Policy and Practice, [online], 2017. 08. 16. Forrás: undp.org [2019. 11. 10.]
} 
magyarázatot. ${ }^{19} \mathrm{~A}$ menekültek többségét adó szegényebb rétegekre tehát ez a két letelepedési minta a jellemző.

Emellett persze van egy kisebb létszámú, vagyoni helyzetéből adódóan tehetősebb rétege is a menekülteknek, amelyre egy harmadik letelepedési minta a jellemző. A menekülteknek ezt a harmadik, gazdagabb csoportját több okból sem lehet az elöző kettőhöz kötni. Elsősorban azért, mert a vagyonos rétegbe sorolható menekültek túlnyomó többsége nem is regisztrálta magát az ENSZ menekültügyi szervezeteinél, másodsorban pedig azért, mert többségük számára Libanon csupán az első állomás egy másik, legtöbbször nyugati célország felé vezető úton, ahol már egy korábban kiköltözött családtag vagy rokon várja érkezésüket. A Libanonban letelepedett „gazdagabb” szíriai réteg sokszor nem is sorolható be a hagyományos értelemben vett menekültek közé, hiszen míg egy menekült gyakorlatilag az életét próbálja menteni, addig a gazdagabb szíriai réteg nem feltétlenül tartozik ebbe a kategóriába. Ahogyan az ENSZ is definiálja, a menekült azért kel útra, mert élete veszélyben van, és leginkább üldöztetése miatt nem tud, vagy nem akar visszatérni hazájába vagy otthonába. ${ }^{20}$ Ehhez képest viszont a polgárháború ellenére sokan még mindig rendszeresen látogatnak haza, illetve kelnek át a szír-libanoni határon. A másik ok ennél sokkal egyszerübb, mégpedig az, hogy az ember egyszerüen nem így képzeli el „a menekültet”. Például, sok az olyan felső-középosztályból származó szír család, akiket házassági kapcsolatok vagy egyéb rokoni szálak füznek libanoni családokhoz. Ezeknek a családoknak a tagjai pedig gyakorlatilag évtizedek óta ingáznak a két ország között, üzleti, családi látogatások vagy akár egyetemi tanulmányok folytatásának céljából egyaránt. ${ }^{21}$ Számos olyan aleppói keresztény vagy örmény család is van, akik a konfliktus elején kiküldték a gyerekeiket a drága libanoni magánegyetemekre tanulni, vagy az ott lévő libanoni rokonaikhoz költöztették őket, esetleg náluk szereztek nekik munkát. Sok például a drúz család, akik a libanoni drúz hegyvidékekre költöztek, miután az ottani rokonaik befogadták öket vagy segítettek nekik jó áron albérletet találni. Emellett akadnak gazdag damaszkuszi üzletemberek is, akik a helyi libanoni rokonság közremüködésével jutottak például bejrúti ingatlanbefektetésekhez, miközben családtagjaik rendszeresen ingáznak Bejrút, Damaszkusz és más külföldi városok között. Bár az ő rétegük egyértelmüen csak egy szűk kisebbséget képvisel, példájuk hozzájárulhat a menekültkérdés problematikájának megértéséhez.

Mindemellett megemlíthetők még olyan húzótényezők is, amelyek idővel a további migrációt ösztönző tolótényezőkké váltak, ami miatt sokan indulnak ismét útnak Európa felé, vagy vágynak inkább vissza Szíriába. ${ }^{22} \mathrm{Az}$ első ilyen a gazdasági tényező, a második pedig a nem kormányzati szervezetek (NGO-k), a különböző civil és karitatív szervezetek tevékenysége, illetve az ENSZ által nyújtott egészségügyi ellátás és oktatási szolgáltatások jelentős szerepe a szíriai menekültek ellátásában Libanon területén. Érdekes fejlemény, hogy miközben ezek a tényezők a konfliktus elején fontos szempontok voltak a menekültek számára a célország kiválasztásakor, addig az utóbbi években már pont ellenkezőleg,

\footnotetext{
Syria Regional Refugee Response, [online], Forrás: unhcr.org [2019. 11. 20.]

What is a refugee?, [online], Forrás: unhcr.org [2019. 11. 16.]

A szerző libanoni származása révén saját családi és ismeretségi köréből, illetve helyi tapasztalatai alapján hoz példákat a menekültekkel kapcsolatos megállapításainak alátámasztására.

22 Seven factors behind movement of Syrian refugees to Europe, [online], 2015. 09. 25. Forrás: unhcr.org [2019. 11. 20.]
} 
éppen e tényezők miatt gondolkodnak el egyre többen azon, hogy újra útnak induljanak. Ennek az egyik fö oka a nem kormányzati szervezetek és egyéb civil szereplők számának és költségvetéseiknek a csökkenése, ${ }^{23}$ másrészt pedig az egyre fokozódó libanoni gazdasági válság, amely miatt a menekültek egyre nehezebben találnak maguknak munkalehetőséget. $^{24}$

Menekült: aki az 1951-es ENSZ menekültügyi egyezmény első cikkének második bekezdése (valamint az 1967-es kiegészítő protokollja) szerint „faji, vallási okok, nemzeti hovatartozása, illetve meghatározott társadalmi csoporthoz való tartozása, avagy politikai meggyőződése miatti üldözéstől való megalapozott félelme miatt az állampolgársága szerinti országon kívül tartózkodik, és nem tudja, vagy az üldözéstől való vélelmében nem kívánja annak az országnak a védelmét igénybe venni; vagy aki állampolgársággal nem rendelkezve és korábbi szokásos tartózkodási helyén kívül tartózkodva nem tud, vagy az üldözéstől való félelmében nem akar oda visszatérni". ${ }^{25}$

Menedékkérő: a fent említetteknek megfelelő személy menedékkérő, míg el nem ismeri menekültnek az állam, amelyhez segítségért fordult. A törvényben meghatározott feltételekkel a menedékkérő jogosult a kérelmét elbíráló ország területén való tartózkodásra, ellátásra, támogatásra, szállásra és munkavégzésre, valamint köteles a menekültügyi hatósággal együttmüködni.

Belső menekült: aki a menekültekkel ellentétben nem külföldön keres menedéket. Bár sokuk a menekültekhez hasonló okból hagyja el otthonát (fegyveres konfliktus, általános erőszak, az emberi jogok megsértése), a belső menekültek védelméről jogi értelemben továbbra is saját kormányuk gondoskodik, abban az esetben is, ha maga a kormány áll a menekülésükhöz vezető események hátterében. ${ }^{26}$

Emigráns: aki menekültekkel ellentétben nem fenyegetés vagy üldöztetés miatt, hanem egy jobb élet reményében kel útra és telepedik le egy másik országban. Mivel az emigránsokat nem éri üldöztetés, ezért ők bármikor biztonságban hazatérhetnek, ha akarnak. Az emigráns vagy migráns tehát egy tágabb fogalom, és nem jogi kategória.

Hontalan: akit saját joga szerint egyetlen állam sem ismer el állampolgárának. ${ }^{27}$

Oltalmazott: Magyarországon az a személy részesülhet oltalmazotti védelemben, aki nem felel meg a menekültté nyilvánítás feltételeinek, de esetében megalapozott annak a veszélye, hogy származási országába történő visszatérése esetén őt súlyos sérelem érné, és nem tudja, vagy az e veszélytől való félelmében nem kívánja hazája védelmét igénybe venni. Az oltalmazott személyt a menekült jogai illetik meg. ${ }^{28}$

Menedékes: Magyarország menedékesként ideiglenes védelemben részesíti azt a külföldit, aki hazájából fegyveres konfliktus, polgárháború, etnikai összecsapás, illetve az emberi jogok általános, módszeres, durva megsértése miatt tömegesen kényszerült elmenekülni. ${ }^{29}$

Befogadott: azt a menedékkérőt, aki ki van zárva a menekült, oltalmazott, illetve menedékes jogállásból, ám a származási országában faji, illetve vallási okok, nemzeti hovatartozása, meghatározott társadalmi csoporthoz tartozása, avagy politikai meggyőződése miatt üldöztetés veszélyének lenne kitéve, és nincs olyan biztonságos harmadik ország, amely befogadja, az idegenrendészeti hatóság befogadottként ismeri el. A befogadottak speciális engedélyt kapnak, amellyel ideiglenesen Magyarországon maradhatnak. ${ }^{30}$

23 Seven factors behind movement of Syrian refugees to Europe: $i . m$.

24 Chloe CoRnish: Syrian refugees in Lebanon face mounting hostility, [online], 2019. 07. 22. Forrás: ft.com [2019. 11. 25.]

25 1989. évi 15. törvényerejű rendelet a menekültek helyzetére vonatkozó 1951. évi július hó 28 . napján elfogadott egyezmény, valamint a menekültek helyzetére vonatkozóan az 1967. évi január hó 31. napján létrejött jegyzőkönyv kihirdetéséről, [online], Forrás: unhcr.org [2020. 01. 17.]

26 Belső menekültek, Menekültként saját hazájukban, [online], 2016. 12. 18. Forrás: unhcr.org [2020. 01. 17.]

27 2007. évi LXXX. törvény a menedékjogról, [online], 2. \$ b) pont. Forrás: net.jogtar.hu [2020. 01. 17.]

28 2007. évi LXXX. törvény a menedékjogról, 12. \$ (1) bekezdés.

29 2007. évi LXXX. törvény a menedékjogról, 19.\$.

30 2007. évi LXXX. törvény a menedékjogról, 25/A-25/B. \$. 


\section{A libanoni menekülthelyzet a számok tükrében}

Megjegyzendő, hogy a Libanonban tartózkodó szíriai menekültek demográfiai súlyának érzékeltetésére a szakirodalomban gyakran kétféle számadatot szoktak megadni. Ennek az egyik oka, hogy a menekültek egy része nem regisztrált az ENSZ rendszerében, az ilyen nem regisztrált menekültek számáról pedig csak becsléseink vannak, és ráadásul a különböző források eltérő becsléseket alkalmaznak. Az ENSZ Menekültügyi Föbiztossága (UNHCR) szerint 2019 őszén összesen 918.974 regisztrált menekült tartózkodott Libanon területén. ${ }^{31} \mathrm{Ez}$ a szám gyors ütemben növekedett a konfliktus elején, így a menekültként regisztráltak száma a csúcsát 2015 áprilisában érte el, megközelítve az 1,2 millió föt. ${ }^{32}$ Ez a szám az elmúlt években 1 millió fö alá csökkent, ugyanakkor a libanoni hatóságok szerint a menekültek valós száma nagymértékben meghaladhatja az ENSZ rendszerében regisztráltak számát, megközelítve a másfél milliót. ${ }^{33}$

A menekülteknek a regisztrációja több okból is elmaradhatott az elmúlt években. Az egyik magyarázat például az adminisztrációs túlterheltség, hiszen a konfliktus első éveiben a masszív menekültáradat gyakorlatilag túlterhelte a menekültügyi ellátórendszert, így az ENSZ és szervezetei nem győzték valamennyi menekült adatait regisztrálni. Mindemellett 2015-ben a libanoni hatóságok fel is szólították az ENSZ szervezeteit, hogy ne regisztráljanak több menekültet. ${ }^{34}$ A regisztráció elmaradásának okai között említhető még továbbá a menekültek hanyagsága vagy inkább „nemtörődömsége” is, hiszen sokan egyszerüen nem tartották fontosnak a regisztrációt, tekintettel arra, hogy a már említett korábbi vízummentesség miatt a szíriai állampolgárok amúgy is szabadon átléphették a szír-libanoni határt, és így legálisan tartózkodhattak Libanon területén. ${ }^{35}$ Ugyanakkor a menekültek egy része például inkább a büszkesége miatt nem akarta hivatalosan menekültként regisztrálni magát. ${ }^{36}$

A szíriai menekülteknek van még egy további csoportja is, akikről általában kevés szó esik a beszámolókban. Ök a szíriai palesztin menekültek, akik a szíriai menekülttáborokból jöttek át társaikkal együtt, és többségük a libanoni palesztin menekülttáborokba ment. ${ }^{37}$ Számuk nem tudható pontosan, de az állam által regisztráltak száma 54 ezer fö körül alakul, ${ }^{38}$ míg mások szerint meghaladja a 90 ezret, amelyből csak 20 ezren maradtak Libanonban, miután sokan vagy visszamentek Szíriába, vagy inkább más országok felé in-

\footnotetext{
Lebanon total registered refugees, [online], Forrás: unhcr.org [2019. 11. 29.]

Uo.

Lebanon Fact Sheet: $i$. m.

34 Fabrice Balanche - Eric Verdeil: The Influx of Syrian Refugees in Lebanon. In: Verdeil, Eric - Faour, Ghaleb Hamzé, Mouin (szerk.): Atlas of Lebanon: New Challenges, New edition, Presses de l'Ifpo, Beyrouth, 2019, 44. o.

35 Maja Janmyr - Lama Mourad: Millions of Syrians' lives depend on whether they're designated as 'refugees', [online], 2018. 03. 06. Forrás: washingtonpost.com [2019. 11. 30.]

37 Ez föleg a Damaszkusz melletti Jarmuk palesztin menekülttábort érinti, ahol a konfliktus első éveiben heves harcok zajlottak és számos erőszakos atrocitás történt. A Szíriából Libanonba átmenekült palesztin menekültek többsége a libanoni palesztin menekülttáborokban (Szaida városa mellett Ayn El Helweh, vagy Tripoli mellett Beddawi) húzta meg magát, legalább is ideiglenesen.

38 Exclusive - Fatah Initiative to Return Syria’s Palestinian Refugees from Lebanon Flops, [online], 2018. 12. 17. Forrás: aawsat.com [2019. 12.04.]
}

36 Uo. 
dultak. ${ }^{39}$ Mindezt azért fontos itt megjegyezni, mert Libanonban már 1948 óta közel félmillió regisztrált palesztin menekült tartózkodik. ${ }^{40}$ Ezeknek a palesztin menekülteknek a többsége a mai napig hontalan, így a fele áldatlan körülmények között, menekülttáborokban él, amelyek egy része az elmúlt évtizedekben a brazil favellákat idéző nyomornegyedekké vált. A létszámukra vonatkozó félmilliós adattal kapcsolatban itt is megjegyzendő, hogy egyesek szerint számuk már megfeleződött, ${ }^{41}$ hiszen sokan harmadik országba emigráltak, így már elhagyták Libanont. ${ }^{42}$ Jelenlétük azonban számos demográfiai problémát és társadalmi feszültséget kelt a libanoniak körében, hiszen túlnyomó többségük szunnita muszlim, ami érzékenyen érinti Libanon törékeny felekezeti és vallási status quóját, és ez a szíriai menekültek esetében is igaz, mivel többségük szintén szunnita. ${ }^{43} \mathrm{~A}$ szíriai és a palesztin menekültek mellett pedig meg kell még említeni az iraki menekülteket is, akiknek a létszáma 10 ezer fö lehet. ${ }^{44}$

Mindezek alapján megállapítható, hogy Libanon napjainkban a legnagyobb arányú menekültpopulációval néz szembe. Az ország lakossága 4-5 millió fö közé tehetö, ${ }^{45}$ a szíriai menekültek száma másfél millió, a palesztin menekülteké pedig 300 ezer körüli, így gyakorlatilag 1,8 millió menekült él egy Magyarországhoz képest kilenced akkora területen. Következésképpen a legóvatosabb becslések szerint is 30\% a menekültek aránya Libanonban. Ráadásul más migrációs célországokhoz képest Libanonban ez a menekültpopuláció nem az államhatárok mentén, illetve állami fenntartású, szervezett menekülttáborokban koncentrálódott, hanem országszerte jelen van. Mivel az állam a menekültválság elején nem szervezte meg a menekültek ellátását, így ad hoc helyzetek alakultak ki, és a menekültek minden koordináció nélkül érkeztek az országba. Idővel minden régiót érintett a menekültkérdés, bár nyilvánvalóan elsősorban a határ menti térségeket, így Észak-Libanon és a keleten fekvő Bekaa-völgy a legérintettebb, ahol a menekültek 37\%-a tartózkodik jelenleg. ${ }^{46}$ A Bekaa völgyét a sorban Észak-Libanon 26\%-kal, Bejrút 25\%-kal, Dél-Libanon térsége pedig $11 \%$-kal követi. ${ }^{47} \mathrm{~A}$ vidéki régiókban a többség rendezetlen táborokban él, és csupán pár család engedhette meg magának egy rossz állapotú ingatlan vagy esetleg egy garázs kibérlését. Vannak, akik elhagyott vagy félkész épületekben húzzák meg magukat, és akadnak olyanok is, akik a munkahelyük által biztosított szolgálati lakásba vagy szobába költöztették be családjukat. ${ }^{48}$ Sokan pedig a palesztin menekülttáborokban

39 Exclusive - Fatah Initiative to Return Syria's Palestinian Refugees from Lebanon Flops: i. m.

40 Where we work: Lebanon, [online], Forrás: unrwa.org [2019. 12. 04.]

${ }_{41}$ Population and Housing Census in Palestinian Camps and Gatherings in Lebanon 2017, [online], Lebanese Palestinian Dialogue Committee, Central Administration of Statistics, Palestinian Bureau of Statistics, 2018. Forrás: lpdc.gov.lb [2019. 12.04.]

42 Lars Erslev Andersen: The neglected: Palestinian refugees in Lebanon and the Syrian refugee crisis, [online], Danish Institute for International Studies, 2016. Forrás: econstor.eu [2019. 12. 04.]

43 Dina Eldawy: A Fragile Situation: Will the Syrian Refugee Swell Push Lebanon Over the Edge?, [online], 2019. 02.21. Forrás: migrationpolicy.org [2019. 12.04.]

44 Uo.

45 Tekintettel arra, hogy 1932 óta nem volt hivatalos állami népszámlálás, csupán becsléseink vannak a libanoni lakosság számára vonatkozóan, amelyek többsége 4-5 millió fö közé teszi a libanoniak számát.

46 Lebanon total registered refugees...: i. $m$.

47 Uo.

48 Ez például a gondnokként dolgozó szírekre jellemző, akik a kis egyszobás szolgálati lakásaikba a családjuk többi tagját is beköltöztették. 
telepedtek le, ahol kedvezőbb bérleti díj ellenében juthattak szobához vagy ingatlanhoz. ${ }^{49}$ A határmenti települések esetében azonban sokszor magasabb a helyi libanoni lakosság számánál a szíriai menekültek száma. Erre az egyik legjobb példa a bekaa-völgyi Erszál települése, ahol előfordult, hogy a menekültek száma elérte a 120 ezer főt, miközben a falusi libanoni lakosság körülbelül 40 ezer föt számlál. ${ }^{50}$

Megjegyzendő, hogy a menekültek túlnyomó többsége szegény, az ENSZ adatai szerint a 69\%-uk él a szegénységi küszöb alatt. ${ }^{51}$ A nemi arányok tekintetében nagyjából fele-fele a megoszlás, tehát körülbelül 50,5\% nő és 49,55\% férfi. ${ }^{52}$ A menekültpopulációnak több mint a fele kiskorú, illetve gyermek..$^{53} \mathrm{Az}$ ENSZ becslései szerint a nagykorúaknak több mint a 75\%-a házas, a fennmaradó $25 \%$ pedig egyedülálló, özvegy vagy elvált. ${ }^{54}$ Mindezen adatok világosan cáfolják azokat a médiaértesüléseket, amelyek szerint a menekültek, illetve „a migránsok nagy többségét katonakorú férfiak” adnák. ${ }^{55}$

\section{Kényes egyensúly}

A libanoni szír menekültek helyzetének, illetve problémáinak megértéséhez elengedhetetlen a sajátos, úgynevezett konszociális libanoni politikai rendszer müködésének ismerete. A libanoni konfesszionális parlamenti demokrácia lényege a hatalom megosztása az ország valamennyi vallási felekezete között. ${ }^{56}$ Igy ennek a rendszernek egyik fontos részét képezi az állam és az állampolgárok között intézményesült köztes felekezeti réteg, amely a gyakorlatban úgy müködik, hogy minden hivatalos állami pozíció kvóták szerint el van osztva az egyes vallási felekezetek között a demográfiai súlyuk alapján, a kereszténymuszlim paritás fenntartása szükségességének szem előtt tartásával. ${ }^{57}$ Ennek megfelelően a mindenkori köztársasági elnök mindig maronita keresztény, a miniszterelnök szunnita muszlim, míg a parlament elnöke síita kell, hogy legyen. Az alelnökök pedig mindig görög ortodoxok. Ez a vallási felekezeti hatalommegosztás a parlamenti képviselői helyek elosztására, illetve a fontosabb vezető közalkalmazotti posztok betöltésére is vonatkozik.

Ennek a rendszernek a működéséhez viszont különösen fontos a felekezetek közötti érzékeny demográfiai megoszlás állandóságának fenntartása, ezért a libanoni állami vezetés úgy határozott, hogy a kényes egyensúly megőrzése, vagy inkább a felekezeti arányokban bekövetkezett változások eltitkolása érdekében inkább nem tart népszámlálást, így átfogó, a felekezeti megoszlásról pontosabb információkat nyújtó demográfiai adatgyüjtést utoljára 1932-ben, még a francia mandátum alatt végeztek. ${ }^{58} \mathrm{Ez}$ a fajta struccpolitika igen

49 Population and Housing Census in Palestinian Camps...: i. $m$.

50 Vivian YeE: In Lebanon Town, Refugees and Locals Agree on 1 Thing: Time for Syrians to Go, [online], 2018. 08.08. Forrás: nytimes.com [2019. 12. 04.]

51 Vulnerability Assessment of Syrian Refugees in Lebanon, [online], 2018. Forrás: unhcr.org [2019. 12. 04.]

52 Uo.

53 Uo.

54 Uo.

55 Lásd például: Hatalmas veszély, hogy a migránsok nagy többsége férfi, [online], 2016. 01. 11. Forrás: 888.hu [2019. 12. 05.$]$

56 Elias Dahrouge - Máté Szalai: A Small State in Constant Crisis: Lebanon after the parliamentary elections of May 2018, [online], 2018. Forrás: kki.hu [2019. 12. 04.]

57 Uo.

58 Rania Mактаві: The Lebanese Census of 1932 Revisited. Who Are the Lebanese? British Journal of Middle East Studies, 26. évf., 1999/2, 219-241. o. 
árulkodó a libanoni status quo megőrzésének problematikáját illetően. Értelemszerüen, bármelyik vallási felekezet demográfiai súlyának növekedése hátrányosan érintené valamennyi másik felekezetet, és ebből a szempontból komoly fejfájást okoz a különböző libanoni eliteknek a szíriai menekültek kérdése. Mivel többségük szunnita muszlim, már puszta jelenlétük is fenyegetést jelent a felekezetek közötti egyensúlyra a keresztény, drúz és a síta közösségek számára egyaránt. Ráadásul még a libanoni szunniták számára sem kívánatos nagyszámú szunnita szíriai menekült megjelenése az országban, noha számukra nem vallási, hanem inkább gazdasági szempontból kényes kérdés a szunnita menekültek problémája. ${ }^{59}$ Továbbá azt sem szabad elfelejtenünk, hogy ahogy azt korábban már említettük, mind a mai napig nem oldódott meg a palesztin menekültek helyzete sem, akik 1948 óta tartózkodnak Libanonban. Mindezek fényében már érthető a libanoni államnak a menekültválsággal kapcsolatos hivatalos álláspontja és a politikai elit hozzáállása.

Elsősorban azt érdemes megjegyezni, hogy Libanon a mai napig nem ratifikálta a menekültek helyzetére vonatkozó 1951-es genfi egyezményt, illetve az ahhoz kapcsolódó 1967-es kiegészítő jegyzőkönyvet. ${ }^{60}$ Ennek egyik fő oka a palesztin menekültek visszatérését szorgalmazó hivatalos állami álláspont, ami más arab országoknál is jellemzően megjelenik. ${ }^{61}$ Tehát, mivel Libanon nem részese a menekültügyi egyezménynek, így nem is ismeri el hivatalosan a menekültstátuszt és az azzal járó jogokat. Sőt, nem is nevezi hivatalosan menekültnek (angolul refugee, arabul „lázsi”) a szíriai menekülteket, hanem inkább csupán az otthonának elhagyására kényszerült hontalan (angolul displaced, arabul „názih”) kifejezést alkalmazza rájuk. A már említett vallási felekezeti egyensúly érzékenysége miatt a libanoni kormány álláspontja a Libanoni Válságkezelési Tervnek (LCRP) megfelelően az, hogy „Libanon se nem menedékhely, se nem végső állomás a menekültek számára, és különösen nem az az ország, ahova áttelepülhetnének" ${ }^{62}$ Éppen ezért, a menekültek helyzete Libanonban marginalizáltnak tekinthetö. ${ }^{63}$

Másodsorban nem elhanyagolható tényező még a menekültkérdés alakulása szempontjából az sem, hogy az első menekülthullámok idején az összetett libanoni politikai rendszer miatt a kormány gyakorlatilag teljesen döntésképtelen helyzetben volt, mivel a miniszterek nem tudtak egymással dülöre jutni semmilyen megállapodást illetően. Ennek pedig az lett a következménye, hogy a libanoni hatóságok egyfajta struccpolitikát követve tulajdonképpen semmit sem tettek a menekülthelyzet kezelése érdekében, sem infrastrukturális fejlesztéseket nem végeztek, sem letelepedési tervet nem készítettek a beáramló menekültpopuláció ellátása érdekében. Így a már említett módon csak ad hoc megoldások születtek, ami azt jelentette, hogy az érintett térségekben a központi kormány reakciójának hiányában gyakran a lépéskényszerbe került helyi önkormányzatok és polgármesteri hivatalok intézkedtek, sokszor törvénytelenül. Például több faluban éjszakai kijárási tilalmat vezettek

\footnotetext{
59 Bővebben lásd: YeE: i. m. A korábban említett, szunniták lakta Ersal településen sem nézik jó szemmel a szíriai menekültek tartós jelenlétét, mivel számukra hátrányosan befolyásolják a munkaerőpiaci helyzetet.

60 Maja Janmyr: No Country of Asylum: 'Legitimizing' Lebanon's Rejection of the 1951 Refugee Convention, International Journal of Refugee Law, 29. évf., 2017/3, 438-465. o.

61 Uo.

62 Lebanon Crisis Response Plan 2015-2016, [online], 2016. 01. 12. Forrás: reliefweb.int [2019. 12. 06.]

63 JANMYR: $i$. $m$.
} 
be a „külföldiekre”, azaz burkoltan, de elég egyértelmüen a szíriai menekültekre vonatkozóan. ${ }^{64}$ Volt, ahol a helyi polgárőrség egyszerüen felszólította a szíreket a távozásra, míg máshol fizikailag is bántalmazta a „szabálysértőket”. ${ }^{55}$ Ezek az esetek föleg vallási alapúak, hiszen a legtöbb ilyen incidens keresztény, síita vagy drúz lakta településeken történik. A helyi önkormányzatok sokszor ilyen eszközökhöz folyamodva igyekeztek a helyi lakosság azon részét megnyugtatni, akikben félelmet váltott ki az „idegenek” jelenléte, és kisebb „pogromok” is elöfordultak, amelyek során a helyi lakosok felgyújtották a szíriai menekültek sátrait. ${ }^{66}$

Harmadik pontként kiemelhető még a szíriai állampolgárokra vonatkozó vízumkényszer bevezetése, amit már korábban is említettünk. 2015 óta tehát a libanoni hatóságok nemcsak hogy megkérték az ENSZ szervezeteit, hogy ne regisztráljanak több menekültet, de még be is vezettek egy új, igen vitatható vízumrendeletet. Lényegében így próbálták a menekültáradatot megfékezni. Az új szabályok értelmében a már Libanonban élő szíreknek is évente tartózkodási engedélyt kell kiváltaniuk, amit kétféle módon tehetnek meg. Vagy kifizetik a tartózkodási engedély 200 dolláros költségét, vagy a „kafála” rendszerhez hasonlóan, egy libanoni személy vállalja értük a felelősséget. Értelemszerüen egy szegény, gyakran többgyerekes családnak fejenként 200 USD kifizetése, ráadásul évente, szinte lehetetlen. ${ }^{67}$ Tehát, maradt a második lehetőség, azaz találni egy munkáltatót, aki vállalja a „kafálát”, és magához veszi a menekültet munkavállalóként, a családjával együtt. ${ }^{68}$ Ám ez szintén egy nehezen járható útja a tartózkodási engedély megszerzésének, így ezeknek az intézkedéseknek az lett az eredménye, hogy 2018-ban a menekülteknek körülbelül a kétharmada de facto illegális státuszban tartózkodott az országban. ${ }^{69} \mathrm{Az}$ illegalitásban lévő szíriai menekültek jelenléte viszont megnövelte a letartóztatások, a zaklatások és a menekültek szabad mozgását korlátozó diszkriminatív intézkedések számát. ${ }^{70}$ Tartózkodási engedély, illetve a szükséges dokumentáció hiányában olyan jelenetek is előfordulnak a szíriai menekültekkel, hogy például a fiát éppen az iskolába kísérö édesapát gyermekével együtt letartóztatja a rendőrség.

Emellett megemlítendő még az önkéntes hazatérések kezdeményezése, amit először 2018-ban indítottak el a libanoni hatóságok, és amelynek keretében az elmúlt években már

64 A szerző libanoni lakóhelyénél a menekülteket hátrányosan érintő helyi önkormányzati döntésekről plakátokat is kihelyeztek.

65 “Our Homes Are Not for Strangers", [online], 2018. 04. 20. Forrás: hrw.org [2019. 12. 06.]

66 Tiffany Kwok: 'Burn the camps': The Dire Condition of Syrian Refugees in Lebanon, [online], 2019. 07. 10. Forrás: natoassociation.ca [2019. 12.06.]

67 Vulnerability Assessment of Syrian Refugees in Lebanon: i. $m$.

68 A „kafála” több arab országban is bevett gyakorlat. Működésének lényege, hogy egy gazdasági bevándorló csak egy „kafil”, azaz egy az ő személyéért és a beutazásáért felelősséget vállaló libanoni állampolgár hozzájárulásával kaphatja meg a munkavállalói és a tartózkodási engedélyt. Ez a rendszer azonban szinte teljesen kiszolgáltatja a szíriai menekült munkavállalókat, akik így gyakran lesznek jogsértések áldozatai. Korábban ez a szabályozás csak az egyiptomi, az etiópiai és az ázsiai vendégmunkásokra vonatkozott, és főleg a házvezetőnőként vagy cselédként foglalkoztatott fiatal nőkre alkalmazták, 2015 óta azonban a szíriai menekültekre is kiterjesztették.

69 Vulnerability Assessment of Syrian Refugees in Lebanon: i. $m$.

70 Uo. 
több tízezer szír menekültnek sikerült megszervezni az önkéntes hazatérését Szíriába. ${ }^{71}$ Ezek a hazatelepítési eljárások azonban számos nemzetközi jogi kérdést felvetnek. Az Amnesty International szerint például egyenesen szabálytalanok, hiszen a „konstruktív visszatelepítés" módszerét alkalmazzák, amelynek lényege, hogy az állam indirekt módon igyekszik visszatérésre ösztönözni embereket egy olyan helyre, ahol fokozottan fennáll az emberi jogi jogsértések kockázata. ${ }^{72}$

Ezekre a lépésekre azonban leginkább azért kerülhetett sor, mert a menekültválságra adott nemzetközi válasz elégtelennek bizonyult. A libanoni kormány így olykor helytelen módszerekkel igyekezett megoldani a menekültválságot, ugyanakkor azt is figyelembe kell venni, hogy ez az óriási menekültáradat komolyan visszavetette az amúgy is gyengélkedő libanoni gazdaságot, és súlyos károkat okozott az ország infrastruktúrájában is. Nagymértékben megnőtt például a munkanélküliségi ráta, ami egyértelműen összefügg a szíriai menekültek számának növekedésével. ${ }^{73}$ Ennek következményeként Libanon igyekezett felkelteni a nemzetközi közösség figyelmét.

Libanon menekültpolitikája a hasonló menekültválsággal szembenéző országok, például Törökország és Jordánia politikájával együtt egy elméleti keretbe illeszthető, mégpedig a „menekült járadékélvező állam” (angolul „refugee rentier state”) koncepciójába, amelynek lényege, hogy a menekültekre hivatkozva igyekeznek nyomást gyakorolni a potenciális donorállamokra, annak érdekében, hogy minél magasabb összegü támogatást tudjanak kiharcolni maguknak. ${ }^{74}$ Ugyanakkor, míg Törökország elsősorban a menekültek Európa irányába történő továbbengedésével fenyegeti az Európai Uniót, Libanon és Jordánia inkább arra tesz rendszeresen ígéretet, hogy a területén tartja őket, amennyiben ehhez megfelelő támogatást, illetve anyagi kompenzációt kap. ${ }^{75} \mathrm{~A}$ libanoni állami vezetők és döntéshozók minden nemzetközi fórumon és eseményen ugyanazt a narratívát képviselik, hangsúlyozva, hogy a libanoniak nagyon vendégszerető módon fogadták a szír honfitársaikat, ugyanakkor a menekültek ellátása komoly terhet ró az ország gazdaságára, az összeomlás elkerülése érdekében pedig anyagi segítségre van szükségük. ${ }^{76} \mathrm{Ez}$ a narratíva tulajdonképpen a libanoni „populista” elitek által képviselt diskurzusra alapoz, amely szerint a szír menekültek miatt mélyül folyamatosan a gazdasági válság, tehát a menekülteket jelöli meg bünbakként. ${ }^{77}$

Látható tehát, hogy milyen okokból, milyen motivációk által vezérelten, milyen válaszokat adott Libanon a menekültválság jelentette kihívásra. A libanoni menekültpolitika egyik meghatározó tényezője a már említett törékeny vallási és felekezeti egyensúly megőrzésének a szükségessége. Ahogy Számi Náder, egy a menekültekkel szembeni félelem-

71 Retour volontaire lundi d’un millier de réfugiés syriens installés au Liban, [online], 2018. 12. 22. Forrás: lorientlejour. com [2019. 12.08.]

72 Why are returns of refugees from Lebanon to Syria premature?, [online], 2019. 06. 12. Forrás: amnesty.org [2019. 12. 08.]

73 Anda DAvid et al.: The economics of the Syrian refugee crisis in neighboring countries. The case of Lebanon, [online], Forrás: erf.org.eg [2019. 12.08.]

74 Gerasimos Tsourapas: The Syrian Refugee Crisis and Foreign Policy Decision-Making in Jordan, Lebanon, and Turkey, Journal of Global Security Studies, 4. évf., 2019/4, 464-481. o.

75 Uo.

76 Uo.

77 Lásd példaul: Liban. Une croisade haineuse contre les réfugiés syriens et palestiniens, [online], 2019. 08. 04. Forrás: orientxxi.info [2019. 12.08.] 
keltést elítélő libanoni elemző is megállapította, Libanon egy pici ország, ahol a számok igenis számítanak. Ahogy Náder fogalmazott: „Libanon már nem tud több szunnitát befogadni! Egyet sem, hogy nyersen fogalmazzak! Már van 300 ezer szunnita palesztin menekültünk. Fenn kell tartanunk az egyensúlyt a különböző szektariánus csoportok között, a szunnita szíriai menekültek befogadása pedig a libanoni formula újragondolását igényelné, és az állam jelenlegi formájának az átalakításába kerülne." ${ }^{78}$ A palesztin menekültkérdés példájából kiindulva a libanoni lakosság joggal félhet attól, hogy a nemzetközi közösség egyszer majd a szíriai menekülteknek a társadalmi integrációjára, esetleg honosítására kérné Libanont. ${ }^{79}$ A libanoniak számára már az is aggodalomra ad okot, hogy a nemzetközi jelentések rendszeresen szólítják fel Libanont a szíriai menekülteknek a gazdaságba történő integrálására, olykor pedig ezt adják meg a nemzetközi támogatások egyik feltételeként.

Végül, de nem utolsósorban pedig érdemes kitérnünk a menekültválság kiindulópontjára, Szíriára. Meg kell még említenünk, hogy az elmúlt években számos gyermek jött világra Libanon területén szíriai menekültek gyermekeként, akiket sehol sem regisztráltak vagy csupán az ENSZ által készült dokumentációban szerepelnek. Ugyanakkor az ENSZ adatai szerint a regisztrációból kimaradó vagy a dokumentációban hiányosan rögzített menekült gyerekek aránya körülbelül 79\% lehet. ${ }^{80}$ A jövőben fontos kérdés lesz majd, hogy a szíriai hatóságok elismerik-e majd ezeknek a menekült gyerekeknek a szíriai állampolgárságát, vagy egy újabb hontalan menekültréteg van kialakulóban, ami Libanon ellátórendszerét fogja terhelni. Mindemellett több olyan intézkedés történt a szíriai hatóságok részéről is, amelyek szintén hátráltatják a menekültek hazatérését. Az egyik ilyen hátrányos kormányhatározat például államosíthatóvá tette a menekültek ingatlanait. ${ }^{81}$ Mindez jól mutatja, hogyan veszélyezteti a szíriai menekültválság az érzékeny libanoni politikai, gazdasági és biztonsági egyensúlyt.

\section{Fókuszban az Akkar régió}

Értelemszerüen a szír-libanoni határrégiók a szíriai menekültválság által leginkább érintett térségek. Mivel először a határokhoz közeli területekre érkeznek a menedékkérők, elsősorban itt is telepednek le ideiglenesen. Libanon ezen régiói azonban az ország legszegényebb részeinek minősülnek, amiket a központi kormányzat évtizedekig teljesen elhanyagolt. Ez megállapítható Dél-Libanon, a Bekaa völgye és föleg Észak-Libanon esetében is. Utóbbi területén a második legmagasabb a szíriai menekültek száma a Bekaa-völgy után, az északlibanoni Akkar tartomány pedig az ország összes régiója közül a legszegényebbnek és a legelhanyagoltabbnak tekinthető. ${ }^{82}$ A tanulmány következő részében az Akkar régióban élő

78 Anchal Vohra: Lebanon Is Sick and Tired of Syrian Refugees, [online], 2019. 07. 31. Forrás: foreignpolicy.com [2019. 12. 08.]

79 Syrian Refugees in Lebanon eight years on: What works and why that matters for the future, [online], 2018. 11.12. Forrás: reliefweb.int [2019. 12. 09.]

80 Vulnerability Assessment of Syrian Refugees in Lebanon: i. $m$.

81 Syria, events of 2018, [online], 2019. Forrás: hrw.org [2019. 12. 09.]

82 Lebanon: Akkar Governorate Profile, [online], 2014. 08. 11. Forrás: reliefweb.int [2019. 12. 03.] 
szíriai menekültek helyzetét ismertetjük a szerző által végzett helyszíni terepmunka tapasztalatai alapján. ${ }^{83}$

Akkar Libanon legészakabban fekvő tartománya, területe 788 négyzetkilométer. ${ }^{84}$ Az ország más tartományaihoz hasonlóan, a földrajzi adottságai, illetve tengerszint feletti magassága szerint Akkar térsége is három részre osztható: egy mediterrán tengerparti mezőgazdasági síkságra vagy medencére, egy közepes magasságú hegyvidékre és egy magasabban fekvő hegyvidékre. A tengerparti medence szélességét tekintve az ország többi tengerparti vidékéhez képest a legszélesebb, így stratégiai fontosságú mezőgazdasági térségnek számít, és a Bekaa-völgy után Libanon második legfontosabb magtáraként szolgál. A tengerparttal párhuzamosan emelkedik ki egy a Libanoni-hegység északi részét képező, átlagosan 700-800 m magasságú hegyvidék, amelynek legmagasabb pontja eléri az 1900 m-t. Akkar tehát egy három földrajzi szintből álló, döntően mezőgazdasággal foglalkozó vidék, területén kisebb-nagyobb falvakkal és településekkel, amelyek lakosai régen hagyományos feudális rendszerben, a termőföldjeikből éltek.$^{85}$ Noha ez a feudális rendszer az 1950-es évek alatt megszűnt, a libanoni kormány teljesen magára hagyta és elhanyagolta ezt a térséget, ahogy gyakorlatilag minden más, Bejrúttól távolabb eső régiót is. Vidékfejlesztési tervek hiányában azonban Akkar a mai napig sem volt képes gazdaságilag felzárkózni, így továbbra is az ország egyik legszegényebb régiójának minősül, miközben ebben a térségben a legmagasabb a menekültek száma. Akkar lakosságának $80 \%$-a vidéki, és többségük szunnita, ezért ezt a térséget sokan az ország szunnita fellegvárának tekintik, bár sok a keresztény (föleg a maronita és a görög ortodox), és jelentős az alavita közösség létszáma is.

Ezeknek a demográfiai adatoknak a tükrében kell tehát értelmezni a szíriai menekülthelyzetet is. Az ENSZ szerint Akkar lakosságának száma összesen 428 ezer fö, és ebből csupán $59 \%$ libanoni, 36\% szíriai menekült, $5 \%$ pedig palesztin. ${ }^{86}$ Itt érdemes ismét megjegyezni, hogy a szíriai és a palesztin menekülteknek is a többsége szunnita, és egyes falvakban a szíriai menekültek száma akár a libanoni falusi lakosság számának a háromszorosát is meghaladja. ${ }^{87}$

Fontos kiemelni, hogy a korábban említett három domborzati szintnek megfelelően a térség társadalmilag is különböző csoportokra osztható. A tengerparthoz közeli síkságokon a Szíriából átkelő alavita parasztság telepedett le, ahol régen szunnita gazdák földjei voltak, később azonban libanoni állampolgárságot kaptak, és a földek egy része végül az ő

\footnotetext{
83 A szerző 2019 januárjában egy csoportos, egyhetes helyszíni kutatómunkában vett részt, amely során kvalitatív, kvantitatív, kérdőíves felmérések mellett interjúkat és fókuszcsoportos vizsgálatokat is végeztek. Az Akkar régióban élő menekültek helyzetét vizsgáló kutatás a Bejrúti Jezsuita Szent József Egyetem (USJ) Politológia Intézetének ARMA (Arab Master in Democracy and Human Rights) mesterképzése keretében valósult meg. A szerző a helyszíni terepmunka főszervezőjének, Carole Alsharabatinak a kutatói asszisztenseként vehetett részt a munkában. A kutatás több témára kívánt fókuszálni, amelyek közül a gyerekek oktatásának problematikája, illetve a menekültek általános életkörülményeinek megismerése emelhető ki. A terepmunka eredményeiről publikáció is készült, amelynek megjelenése jelen kézirat lezárásakor épp folyamatban volt. A jelen tanulmányban a szerző az akkori megfigyelései alapján tesz további kiegészítő megjegyzéseket.

84 Uo.

85 Layla Moubayed: Establishing Conflict Resilient Communities in the North of Lebanon, [online], 2013. 08. Forrás: partnersbg.org [2019. 12.03.]

86 Lebanon: Akkar Governorate Profile, [online], 2019. 06. 21. Forrás: data2.unhcr.org [2019. 12. 09.]

87 Uo.
} 
tulajdonukba került. ${ }^{88}$ A középhegységekhez tartozó területeken hagyományosan a keresztény nemesség és az egyház volt régen a földbirtokos, miközben a földjeiken a szunnita parasztság dolgozott. Azóta persze sokat változott a helyzet, így mára sok szunnita tudta birtokába venni ezeket a földeket. A magas hegyek viszont mindig is a száműzöttek és a törvényen kívüli emberek menedékeként szolgáltak, mivel ezekre a területekre már végképp nem ért el az állam keze.

Az említett domborzati szintek mindegyikén élnek az elmúlt években letelepedett szíriai menekültek, és sorsuk a szintekhez köthető társadalmi helyzetnek megfelelően más és más. Valamennyi szír menekült számára a fö fenyegetést az Aszad-rezsim, tehát saját kormánya jelenti, ezért sem akarnak visszatérni hazájukba. Bár a libanoni szunniták szimpatizálnak a szíriai szunnitákkal, ugyanakkor a legtöbb akkari alavita viszont az Aszad-rezsimet támogatja. A libanoni menekülthelyzet vizsgálatakor ezt is figyelembe kellett venni, így mindhárom térségben külön mintát választottunk ki az adott menekültpopulációból.

\section{A menekülttáborok és a befogadó települések}

A helyszínen végzett kutatómunka során összesen hét helyszínt kerestünk fel, amelyekből öt sátortábor volt, kettő pedig falu, ahol a menekültek szétszórtan élnek lepusztult ingatlanokban vagy termőföldek szélén felvert sátraikban, vagy akár garázsokban is. A sátortáborokat mind a tengerszinten fekvő sík terepen alakították ki Tel Abbász és Híssza falvak környékén, míg a falvak a középhegységi szinten (Bkerzla), és a magasabban fekvő hegyvidéken (Mismis) találhatók. A menekülttáborok lakóinak a társadalmi háttere is igen változónak tekinthető, vannak közöttük falusi szedentáris vidéki szírek és vannak közöttük városi vagy külvárosi származásúak is. Sok közöttük a szír beduin is, a Híssza táborban pedig szinte az összes menekült a domari nawar kisebbségből származik, amely a levantei térség egyik legdiszkrimináltabb cigány kisebbsége. E menekültpopulációk között lényeges eltérések vannak, szegregáltan élnek, csak nagyon ritkán vegyülnek egymással egy adott helyszínen. Értelemszerűen az egyes területekre jellemző eltérő környezeti adottságok miatt is máshogy alakult az egyes menekültközösségek sorsa, illetve helyzete.

A tengermenti táborok lakói szinte mind mezőgazdasági tevékenységet folytatnak. Egyes területekre jellemző, hogy olyan szíriai menekültek élnek és dolgoznak az ott található földeken, akik már a szíriai polgárháborút megelőzően is rendszeresen jártak át Szíriából idénymunkát végezni, a konfliktus fokozódásával pedig gyakorlatilag sátrat vertek és áthozták családjaikat, törzsi rokonaikat és ismeröseiket is. Olyan menekültek is akadnak, akik viszont teljesen véletlenül keveredtek ezekre a területekre. Viszont, mindannyiuknak bérleti díjat kell fizetnie a földek tulajdonosainak ott-tartózkodásukért, amivel a helyi gazdák igen jól járnak, hiszen sokkal egyszerübb számukra a földjeik éves bérbeadásával jövedelemhez jutni, mint a mezőgazdasági tevékenységből, földmüvelésből és a termény értékesítéséből. Erre az egyik legjobb Tel Abbász példája, ahol egy idős falusi embernek az udvarából nyíló telkén található egy 25-30 sátorból álló menekülttábor. Elmondása szerint korábban dohánytermelésre hasznosította a földjét, mivel van rá állami engedélye. A menekültválság

88 Local and Regional Entanglements: The Social Stability Context in Sahel Akkar, [online], 2016. Forrás: reliefweb.int [2019. 11.25.] 
kezdete óta azonban sokkal jobban jár anyagilag azzal, hogy kiadja a menekülteknek, hiszen így nemcsak hogy nem kell dolgoznia a telken, de a magasabb bérleti díj miatt amúgy is több pénz üti a markát. Ami pedig a dohánytermelést illeti, mivel az Libanonban állami monopólium, ezért engedélyhez kötött, és a termelő csak az államnak adhatja el az áruját. A telkét kiadó úr viszont így kedvező áron felvásárolhatja az engedély nélkül termelőktől a dohánytermékeket, majd eladhatja azokat az államnak. Ebben az esetben a földjét bérbeadó falusinak nem volt semmi problémája a szíriai menekültekkel. Ugyanakkor előfordult olyan eset, ahol az alavita származású gazda összetüzésbe került a rezsimellenes szunnita menekültekkel.

Bkerzla faluban a menekültek többsége garázsokat bérelt ki magának, egy részük pedig a munkáltatójuk által biztosított szobában lakik. Sok közöttük a falusi szedentáris „fellah”, de van egy kisebb, beduin származású szíriai menekültek által lakott, hét-nyolc sátorból álló alkalmi tábor is. Ök valamennyien ugyanabból a beduin törzsből származnak. Ebben a közösségben is jellemző, hogy a férfiak rendszeresen jártak át Szíriából idénymunkát végezni libanoni földeken, ahol a helyi gazda a telke szélén egy szezonális kunyhót vagy sátrat biztosított nekik az idényre. Ebben az esetben is az történt, hogy a szíriai fegyveres konfliktus kitörésével az idénymunkások áthozták magukkal családjuk többi tagját a telkekre, köztük nőket, gyerekeket és időseket is. Az ilyen „áttelepülések” hírének elterjedésével a családok távolabbi törzsi rokonai, barátai vagy régi szomszédjai is igyekeztek követni a példájukat. Ennek eredményeként a sátrak száma is megnövekedett, a tábor gyarapodásával pedig a gazdák az újonnan érkezett menekültektől is elkezdték beszedni a bérleti díjat. Gyakorlatilag így, teljesen szabályozatlanul, mondhatni ad hoc alakult ki számos menekülttábor egy-egy telek szélén, a helyi önkormányzatok hallgatólagos beleegyezésével. A civil szervezetek és az ENSZ nem vettek részt a táborok kialakításában, csak később kapcsolódtak be a menekültek ellátásába. Legtöbbször a higiéniai állapotokat igyekeztek javítani, például mobil WC-k vagy víztartályok telepítésével.

A kutatásban szereplő maronita falu történetéből is érzékelhető a menekültválság trendjeinek alakulása, ahova az elmúlt években sem érkezett teljesen „idegen” menekült, mivel a polgármester a helyi lakosság félelmeire tekintettel nem engedélyezte letelepedésüket a faluban. A falusiak tartanak a más vallású, nyomorban élő szíriai menekültektől, így csakis a korábbról már ismert munkáscsaládoknak a letelepedését engedélyezték.

Az 1200 m magasan fekvő szunnita faluban, Mismisben, ahol körülbelül ezer menekült (200 család) él, viszont teljesen más a helyzet. Mivel a 18 ezer fős Mismis libanoni lakosainak a fele külföldi emigrációban él (föleg Ausztráliában), a hasonló kultúrájú szíriai menekültek számára a libanoniak bérbe adták a lakásaikat és az ingatlanaikat. A tulajdonosok Libanonban maradt rokonai gyüjtik be a bérleti díjakat, miközben jó szomszédi viszonyban élnek együtt egymás mellett, már évek óta. Nemcsak hogy együtt kávéznak és gyermekeik is együtt játszanak, de sok vegyes házasság is köttetett a polgármester elmondása szerint. Az ENSZ és a civil szervezetek által biztosított segélyekhez való hozzájutás kérdése mellett pont a vegyesházasságok váltak a második feszültségfokozó tényezővé, mivel sok libanoni nő rossz szemmel nézi, hogy a szíriai nők elhódítják a jóképü falusi férfiakat vagy - muszlim vallásukból adódóan - második feleségként egy szír nőt vesznek el. 


\section{Tábortípusok: változó szintü szervezettség és erőviszonyok}

A nyugati országok állampolgárai számára nehéz elképzelni, hogyan élnek a menekültek a táboraikban a mindennapokban, illetve milyen szervezeti hierarchia alakul ki az ilyen közösségekben. Majdnem minden menekülttáborban kialakul egy bizonyos közösségi tagozódás, illetve rangsor a helyi erőviszonyoknak megfelelően, amelynek élén az úgynevezett „savís” (Shawish), azaz a tábor szóvivője, illetve vezetője áll. ${ }^{89} \mathrm{Ez}$ a pozíció leginkább azért jött létre, hogy az adott menekülttáborban a közösség érdekeit tudja képviselni, tárgyaljon a helyi hatóságok képviselőivel, és biztosítsa a tábor biztonságát. Ugyanakkor az egyes menekülttáborok vezetésére kijelölt személy igénye az ENSZ, a libanoni hatóságok és a civil szervezetek részéről is megfogalmazódott, hogy legyen kivel tárgyalni, egyeztetni, információkat, adatokat beszerezni, hiszen képtelenség másfél millió emberrel személyes kapcsolatban lenni. A savís a legtöbb esetben egy a helyiek által már régebb óta ismert személy, például évek óta Libanonban dolgozó vendégmunkás, aki így komoly helyi tapasztalatokkal rendelkezik, ismeri a helyi lakosokat és az önkormányzattal is jó kapcsolatokat ápol. Emellett kerülhet még ilyen vezető pozícióba egy karizmatikus, hatalommal vagy erőfölénnyel rendelkező személy is, akit esetleg a UNHCR választ ki, vagy csak egyszerüen úgy alakulnak a helyi erőviszonyok, hogy ő kerül a tábor élére. A kisebb méretü menekülttáborokban a rokoni viszonyok a meghatározóak, így a tágabb családi, illetve európai szemszögből inkább a törzsi hierarchiák müködnek továbbra is. Ebben az esetben a savís kimondottan törzsi alapon, a közösség legkiemelkedőbb személyeként kapja meg ezt a titulust. Ez a hatalmi viszonyszerkezet sokszor nagyon igazságtalan helyzetekhez vezet, hiszen gyakorlatilag a savís kezében van a táborban élő menekültek sorsa, ő határozza meg életkörülményeiket. ${ }^{90} \mathrm{~A}$ menekülttáborok életének sokszínűségét jól példázzák a következő bekezdésekben ismertetett esetek.

Az első példánk egy a szíriai Al-Quszajr-ból származó menekültek által Tel Abbász térségében kialakított tábor esete, ahol a menekültek többsége igényesen élö, müvelt ember. Ennek a tábornak a vezetője „Abdó sejk”, aki Szíriában már korábban is kiemelt társadalmi szereplő volt, így nem meglepő módon a tábor lakói egyhangúlag választották meg savísnak, bízva abban, hogy a legjobban ő tudja majd képviselni őket a libanoni hatóságokkal való tárgyalások, valamint a segélyszervezetekkel történő kapcsolattartás során. Például Abdó sejk egyeztetett az önkormányzattal arról, hogy hol verhetik fel a menekültek a sátraikat, ő kérvényezte a libanoni állami villamosmüvektől az elektromosáram-szolgáltatás biztosítását a tábor számára, ő gyüjti össze a telek bérleti díját a lakóktól egyesével és fizeti ki egy összegben a földtulajdonost. Ez, a nagyjából 35 háztartásból álló tábor viszonylag jó állapotúnak, rendezettnek mutatkozott, és az ott lakó menekültekkel folytatott beszélgetéseink alapján a kialakult közösségi szerkezet is elég demokratikusnak bizonyult.

89 A „Shawish” egy oszmán eredetű szó, ami a levantei országokban maradt fenn, bár megváltozott jelentéssel. Régen shawish-nak hívták a csendőrt vagy polgárőrt, de az egy cellában fogvatartott rabok vagy foglyok általuk kijelölt szóvivőjét is így nevezik.

90 Lásd például: Malek AвU KheIR: The Syrian camps shawish: A man of power and the one controlling the conditions of refugees, [online], 2016. Forrás: undp.org [2019. 12. 10.] 
A második példánk egy szaúdi emír által finanszírozott menekülttábor Tel Abbászon, amely igen érdekes történettel rendelkezik. A helyiek elmondása szerint a tábor minden költségét, a villanyszámlától kezdve a mindennapi ellátáson keresztül a telek bérleti díjáig mindent, a szaúdi emír állja, aki szeret jótékonykodni. Ez a körülbelül 50 családból álló tábor nagyon jól szervezettnek mutatkozott, gyakorlatilag egy hosszan kivilágított, afféle föutcának tekinthető út mentén építették fel a sátrakat, a tábor végén pedig található egy müvelödési házként és egy mecsetként funkcionáló nagyobb sátor is, utóbbinak ráadásul még egy fa minaretet is barkácsoltak. Ennek a tábornak a vezetőjét közvetlenül az emír választja ki e menekültek közül, aki a kijelölésétől kezdve gyakorlatilag a tábor „köztársasági elnöke". Ỏ dönti el, hogy ki juthat be oda, a belépésnek pedig komoly eljárási szabályai vannak. Mivel az emír szaúdi konzervatív, gyakorlatilag csak az iszlám törvénykezést, a sariát betartó személy kerülhet be ebbe a táborba, a nőknek kendőt kell viselniük, a gyerekeknek pedig a helyi libanoni iskola helyett a közelben található kuvaiti, a Korán tanítását középpontba helyező iskolába kell járniuk. Ennek a tábornak a példája jól mutatja, hogy a szaúdi vahabizmus szellemében hogyan alkalmazzák az egyes puha hatalmi eszközöket a kiszolgáltatott helyzetbe került szíriai menekültekkel szemben.

A harmadik példánknak az áldatlan körülmények uralta hísszai tábort választottuk, amelynek lakói föleg beduin és nawar származású menekültek, ahogy azt már korábban is említettük. Ebben a táborban a sávis a tényleges törzsi dinamikáknak megfelelően került vezető pozíciójába, és az ott élő menekültek elmondása alapján gyakran visszaélt a hatalmával. ${ }^{91} \mathrm{Az}$ ő sátra volt a legszebb és a legnagyobb, nagyképernyős LCD-televízióval felszerelve, amellyel a táborban elhelyezett kamerarendszeren keresztül figyelte a többi menekültet. Mindemellett egy BMW X5 típusú személygépkocsival is rendelkezett, amelynek egy külön sátrat állítottak fel garázsként. A térségben tevékenykedő civil szervezetek munkatársainak és néhány bátor táborlakó elmondása szerint minden segélyszállítmány az ő jóváhagyásával, csak és kizárólag rajta keresztül érkezhet a táborba. Minden bizonynyal egy részét saját tulajdonába is veszi a segélyeknek, amit később áruba bocsájt más menekültek számára. A tábornak helyet adó telek bérleti díjának a kifizetését is ő intézi, és valószínűsíthető, hogy a szükséges összegnél többet kér el a tábor lakóitól, hogy a különbözetet félretehesse saját magának. Mindemellett a munkáltatók számára egyfajta fejvadászként is funkcionál. Ő szervezi a tábor lakói számára az egynapos mezőgazdasági munkákat, amiért viszont a gazdák neki fizetik ki a munkabéreket, ő pedig valószínűleg ismét csak a munkával kiérdemelt összeg egy részét adja oda a munkásoknak. Az ebben a körülbelül 90 sátorból álló táborban lakó menekültek helyzetét tovább nehezíti, hogy egy kietlen szántóföld közepén, áldatlan körülmények között kell élniük nap mint nap, a civil szervezetek segítségét nélkülözve.

\section{Munkavállalási nehézségek és kiszolgáltatottság}

Laikusok számára szintén nehéz elképzelni, hogyan tudják a menekültek finanszírozni mindennapi kiadásaikat. Főleg az előbb említettek fényében, úgy, hogy még a sátruknak

91 Ott-tartózkodásunk során volt, aki két sátor között megbújva, félve mesélte el a tábor vezetőjének visszaéléseit. 
helyet adó parcelláért is bérleti díjat kell fizetniük a tulajdonosoknak, ami évente átlagosan 600-700 USD sátranként. Emellett még vizet kell venniük tartályokban, fizetniük kell az elektromos áramért (hacsak nem illegálisan jutnak hozzá), szükségük van generátorra, illetve fütőanyagra. Utóbbira értelemszerüen leginkább a magas hegyekben van igazán szükség, ahol télen akár több méter hó is eshet. Ezeket az alapkiadásokat figyelembe véve egy család sátrának a havi költségei egy kisebb budapesti lakás havi rezsijéhez közelítenek.

Mindeközben az ENSZ adatai szerint a menekültháztartások csupán 68\%-ának van legalább egy dolgozó tagja, aki legalább részben el tudja látni a családot, ${ }^{92}$ bár az anyagi kiadásokra a regisztrált menekültek kapnak valamennyi (minimális, folyton változó mértékü) anyagi támogatást. Vannak fix jövedelmű munkavállalók is a menekültek között, például gondnokok, traktorosok, mosogatók vagy felszolgálók. A legtöbb munkavállaló azonban csak egynapos munkákat kap, amiért órabérben vagy napibérben fizetnek neki. A mezőgazdasági munkalehetőségek gyakorlatilag erre a menekülteket egynapi munkával foglalkoztató modellre épülnek, amelyben meghatározó szerepet töltenek be a savís uralta helyi erőviszonyok, aki miatt a menekültek gyakran kerülnek kiszolgáltatott helyzetbe. Ez legföképpen a hísszai menekülttáborban volt tapasztalható, ahol a savís határozottan magához ragadta a hatalmat és így tartja kiszolgáltatott helyzetben a többi táborlakót. Ez a gyakorlatban úgy néz ki, hogy a helyi gazdák neki jelzik a munkaerőigényüket, majd ő dönt arról, hogy az adott munkalehetőséget kik kaphatják meg. A „kiválasztottak” munkabérét közvetlenül a savísnak fizetik ki a gazdák, aki pedig csak azt követően osztja majd szét a fizetéseket a munkavállalók között, hogy az összeg egy részét eltette saját magának. Megjegyzendő, hogy a nők bére csupán a fele a férfi munkavállalók bérének, így a gazdák inkább a nőket szeretik alkalmazni. A savís viszont gyakran úgy állapodik meg a gazdákkal, hogy férfi és nö munkavállalót is küld dolgozni valamilyen arányban. ${ }^{93}$

\section{A gyerekek iskoláztatásának kérdése}

A gyerekek oktatásával kapcsolatban is több eltérő trend figyelhető meg. Az UNICEF és a libanoni oktatási minisztérium között született megállapodás szerint a libanoni állami iskolák délután fogadják a szíriai menekült gyerekeket. Ennek megfelelően a libanoni gyerekek reggeltől délután 14:00 óráig vannak iskolában, 15:00 és 19:00 között pedig a szír gyerekek, akiknek az oktatását az ENSZ finanszírozza, például a libanoni tanárok túlóráinak a kifizetésével. Problémát jelent ugyanakkor, hogy a libanoni oktatás főleg franciául (ritkán pedig angol nyelven) zajlik, míg a szír gyerekek korábban arabul tanultak Szíriában. Emellett még a már Libanonban született szíriai menekülteknek sem igazán megfelelő a libanoni oktatási rendszer, mivel az nagyban támaszkodik a gyermek

92 Vulnerability Assessment of Syrian Refugees in Lebanon: i. $m$.

93 A szerzőnek az adott tábor vezető pozícióját betöltő savís büszkén magyarázta a sátrában, hogy ő gyakran úgy állapodik meg a gazdákkal, hogy például egy tíz főt igénylő munkára hat nőt és négy férfit is küld. Mindemellett pedig elmondása szerint ő személyesen garantálja a munkavállalók jogait, hiszen jó kapcsolatokat ápol a gazdákkal. Mindazonáltal számtalan olyan esetről lehetett hallani, ahol a helyiek kihasználták az illegális munkavállalókat, és nem fizették ki bérüket, mivel kiszolgáltatott helyzetükből adódóan úgysem tudják rajtuk behajtani. 
szüleinek a segítségére, például a házi feladatok megoldásában történő közreműködésre, gyakoroltatásra. A szír gyerekeknek a szülei viszont soha nem tanultak franciául vagy angolul, hiszen Szíriában az oktatás nyelve egységesen az arab. A menekült gyerekeknek az oktatása pedig így nem lehet igazán hatékony. Bár néhány civil szervezet részéről már indult a házi feladatok felügyeletét biztosító eredményes kezdeményezés, ezek az erőfeszítések azonban messze nem elegendőek a probléma megoldásához.

Itt érdemes újra megemlíteni a szaúdi táborban lakó szíriai menekült gyerekek sorsát, akik, ahogy már említettük, kuvaiti vallási iskolába járnak, ami egy Korán-iskola, tehát az oktatás a Korán elöírásai szerint zajlik. Az eddigi tapasztalatok szerint az általános iskola elvégzését követően ezek a gyerekek nem tudtak bejutni a libanoni gimnáziumokba, mert nem voltak meg a felzárkózásukhoz szükséges alapismereteik. A segélyek elapadásával az ENSZ 2019-ben megszüntette az iskolabusz-támogatást, ami eddig nagymértékben megkönnyítette a regisztrált szír menekültcsaládok gyermekei számára az iskolába járást. Így sok gyermek újra kiesett az iskolarendszerből, mivel a szülők nem tudják elvinni a gyerekeiket a gyakran kilométerekre található iskolákba. Ebben a nyilvánvaló anyagi okok mellett az is közrejátszik, hogy a szülöknek dolgozni kell, illetve az illegális státuszú menekülteknek a tartózkodási engedély bevezetése óta gyakorlatilag bujkálni kell a hatóságok elől, nehogy a rendőrség vagy a hadsereg járőrei igazoltassák és letartóztassák őket.

\section{Konklúzió}

A szíriai menekültválság egy igen összetett problémát jelent, a migrációt befolyásoló tényezők ugyanakkor megfelelő magyarázatot adnak arra, hogy miért éppen Libanon lett a menekültáradat által az egyik leginkább érintett ország. A rendelkezésre álló adatok alapján megismerhető, hogy az ország mely térségeiben telepedtek le menekültek a legnagyobb számban, amelyből pedig levezethető, hogy jelenlétük milyen hatással lehet a sajátos berendezkedéssel rendelkező libanoni társadalom vallási és felekezeti megoszlásának kényes egyensúlyára.

Kijelenthető, hogy gyakorlatilag egész Libanont érzékenyen érinti a menekültválság, noha a menekültek többsége az ország határvidékein, sokszor a legelhanyagoltabb térségekben lelt menedékre. A bemutatott letelepedési minták rávilágítanak arra, hogy a menekültek hogyan érkeztek és maradtak Libanonban, míg a migrációt ösztönző toló- és húzótényezők segítenek választ adni a miért kérdésére. Továbbá igyekeztünk bemutatni, hogy a hatóságok és az állami vezetés milyen válaszokat adott a menekültáradat jelentette kihívásra, ha adott egyáltalán. A felekezeti arányokban bekövetkező változás lehetőségét fenyegetésként értékelö állami döntéshozók és egyéb szereplök láthatóan igyekeznek a járadékvadászatra épülő stratégiát követni, a menekültválságot pedig a nemzetközi közösség anyagi áldozatvállalásától függően kezelni. Mindeközben a menekültek túlnyomó többsége kiszolgáltatottan, sokszor áldatlan körülmények között éli mindennapjait, amelyre a helyszínen végzett megfigyeléseink kellő bizonyítékul szolgáltak. A szerző ezért is igyekezett saját, helyszíni tapasztalatai alapján hozott példákkal bemutatni a menekültek életének kihívásait, hogy az olvasó e beszámolók tükrében reális képet kaphasson a libanoni menekültek helyzetéröl. 
A szíriai menekültválság joggal nevezhető a 21. század egyik legborzalmasabb humanitárius katasztrófájának. Sokat kellett türnie Libanonnak is az utóbbi években, hiszen lakossági arányait tekintve a legtöbb menekültet befogadó ország, a menekültek számának sorrendje szerint pedig a negyedik. ${ }^{94}$ A szíriai menekültek megjelenése komoly feszültségkeltő hatással volt az ország társadalmi és politikai dinamikáira, miközben rontott az infrastruktúrák állapotán, mélyítette a gazdasági válságot és károsította a környezetet is. A libanoni gazdasági válság további elmélyülése esetén a menekültek kiszolgáltatottsága is csak fokozódni fog, különösen akkor, ha a nemzetközi közösség is magukra hagyja őket. A szíriai fegyveres konfliktus tehát hatalmas károkat okozott Libanonnak belpolitikai, biztonsági és gazdasági szempontból egyaránt. Többek között a szárazföldön elszigetelte az országot a levantei régió és az Öböl-térség belsejétől, amivel például ellehetetlenítette a mezőgazdasági exporttevékenységet. A menekültválság a szíriai fegyveres konfliktusnak így csupán az egyik fö következménye. A polgárháború regionális hatásai pedig minden bizonnyal még számos hazai és nemzetközi tanulmánynak szolgálhatnak majd kutatási témául.

\section{FELHASZNÁLT IRODALOM}

1989. évi 15. törvényerejü rendelet a menekültek helyzetére vonatkozó 1951. évi július hó 28. napján elfogadott egyezmény, valamint a menekültek helyzetére vonatkozóan az 1967. évi január hó 31. napján létrejött jegyzőkönyv kihirdetéséről, [online], Forrás: unhcr.org [2020. 01. 17.]

2007. évi LXXX. törvény a menedékjogról, [online], Forrás: net.jogtar.hu [2020. 01. 17.]

Abu KheIr, Malek: The Syrian camps shawish: A man of power and the one controlling the conditions of refugees, [online], 2016. Forrás: undp.org [2019. 12. 10.]

Andersen, Lars Erslev: The neglected: Palestinian refugees in Lebanon and the Syrian refugee crisis, [online], Danish Institute for International Studies, 2016. Forrás: econstor.eu [2019. 12. 04.]

Balanche, Fabrice - Verdeil, Eric: The Influx of Syrian Refugees in Lebanon. In: Verdeil, Eric - Faour, Ghaleb - Hamzé, Mouin (szerk.): Atlas of Lebanon: New Challenges, New edition, Presses de l'Ifpo, Beyrouth, 2019, 44-45. o. DOI: https://doi.org/10.4000/books.ifpo.13226

Belső menekültek, Menekültként saját hazájukban, [online], 2016. 12. 18. Forrás: unhcr.org [2020. 01. 17.]

Bou Khater, Lea: Labour Policy and Practice, [online], 2017. 08. 16. Forrás: undp.org [2019. 11. 10.]

Connor, Phillip: Most displaced Syrians are in the Middle East, and about a million are in Europe, [online], 2018. 01. 29. Forrás: pewresearch.org [2019. 11. 19.]

Connish, Chloe: Syrian refugees in Lebanon face mounting hostility, [online], 2019. 07. 22. Forrás: ft.com [2019. 11.25.]

Dahrouge, Elias - Szalai Máté: A Small State in Constant Crisis: Lebanon after the parliamentary elections of May 2018, [online], 2018. Forrás: kki.hu [2019. 12. 04.]

David, Anda - Marouani, Mohamed Ali - Nahas, Charbel - Nilsson, Björn: The economics of the Syrian refugee crisis in neighboring countries. The case of Lebanon, [online], Forrás: erf.org.eg [2019. 12. 08.] DOI: https://doi.org/10.1111/ecot.12230

Eldawy, Dina: A Fragile Situation: Will the Syrian Refugee Swell Push Lebanon Over the Edge?, [online], 2019. 02. 21. Forrás: migrationpolicy.org [2019. 12. 04.]

94 Vulnerability Assessment of Syrian Refugees in Lebanon: i. m. 
Exclusive - Fatah Initiative to Return Syria’s Palestinian Refugees from Lebanon Flops, [online], 2018. 12. 17. Forrás: aawsat.com [2019. 12. 04.]

Federman, Josef - Akour, Omar: Trapped in Jordan, Syrian refugees see no way home, [online], 2019. 10. 11. Forrás: apnews.com [2019. 11. 19.]

GHANEM, Esperance: Lebanese visa regulations cause more distress for Syrians, [online], 2015. 01. 22. Forrás: al-monitor.com [2019. 10. 11.]

Global Trends: Forced Displacement in 2018, [online], 2019. Forrás: unhcr.org [2019. 11. 19.]

Hatalmas veszély, hogy a migránsok nagy többsége férfi, [online], 2016. 01. 11. Forrás: 888.hu [2019. 12. 05.]

Hoкаyem, Emile: Iran, the Gulf States and the Syrian Civil War, Survival: Global Politics and Strategy, 56. évf., 2014/6, 59-86. o. DOI: https://doi.org/10.1080/00396338.2014.985438

An introduction to 'push' and 'pull' factors, [online], Forrás: futurelearn.com [2019. 11. 17.]

Janmyr, Maja - Mourad, Lama: Millions of Syrians' lives depend on whether they're designated as 'refugees', [online], 2018. 03. 06. Forrás: washingtonpost.com [2019. 11.30.]

Janmyr, Maja: No Country of Asylum: 'Legitimizing' Lebanon's Rejection of the 1951 Refugee Convention, International Journal of Refugee Law, 29. évf., 2017/3, 438-465. o. DOI: https://doi.org/10.1093/ijrl/eex026

KwoK, Tiffany: 'Burn the camps': The Dire Condition of Syrian Refugees in Lebanon, [online], 2019. 07. 10. Forrás: natoassociation.ca [2019. 12. 06.]

Lebanon: Akkar Governorate Profile, [online], 2014. 08. 11. Forrás: reliefweb.int [2019. 12. 03.]

Lebanon: Akkar Governorate Profile, [online], 2019. 06. 21. Forrás: data2.unhcr.org [2019. 12. 09.]

Lebanon Crisis Response Plan 2015-2016 [online], 2016. 01. 12. Forrás: reliefweb.int [2019. 12. 06.]

Lebanon Fact Sheet, [online], 2019. 02. Forrás: unhcr.org [2019. 11. 30.]

Lebanon Factsheet, [online], 2019. 08. 26. Forrás: ec.europa.eu [2019. 11. 19.]

Lebanon total registered refugees, [online], Forrás: unhcr.org [2019. 11. 29.]

Liban. Une croisade haineuse contre les réfugiés syriens et palestiniens, [online], 2019. 08. 04. Forrás: orientxxi. info [2019. 12. 08.]

Local and Regional Entanglements: The Social Stability Context in Sahel Akkar, [online], 2016.08. Forrás: reliefweb.int [2019. 11.25.]

Maktabi, Rania: The Lebanese Census of 1932 Revisited. Who Are the Lebanese?, British Journal of Middle East Studies, 26. évf., 1999/2, 219-241. o. DOI: https://doi.org/10.1080/13530199908705684

MouAwAD, Jamil: Lebanon's border areas in light of the Syrian war: New actors, old marginalisation, [online], 2018. Forrás: European University Institute, Robert Schuman Centre for Advanced Studies RSCAS/Middle East Directions 2018/03 [2019. 11. 11.]

Moubayed, Layla: Establishing Conflict Resilient Communities in the North of Lebanon, [online], 2013. Forrás: partnersbg.org [2019. 12. 03.]

“Our Homes Are Not for Strangers", [online], 2018. 04. 20. Forrás: hrw.org [2019. 12. 06.]

Population and Housing Census in Palestinian Camps and Gatherings in Lebanon 2017, [online], Lebanese Palestinian Dialogue Committee, Central Administration of Statistics, Palestinian Bureau of Statistics, 2018. Forrás: lpdc.gov.lb [2019. 12.04.]

Retour volontaire lundi d'un millier de réfugiés syriens installés au Liban, [online], 2018. 12. 22. Forrás: lorientlejour.com [2019. 12. 08.]

Seven factors behind movement of Syrian refugees to Europe, [online], 2015. 09. 25. Forrás: unhcr.org [2019. 11.20.]

Syria, events of 2018, [online], 2019. Forrás: hrw.org [2019. 12. 09.]

Syria Regional Refugee Response, [online], Forrás: unhcr.org [2019. 11. 20.]

Syrian Refugees in Lebanon eight years on: What works and why that matters for the future, [online], 2018. 11. 12. Forrás: reliefweb.int [2019. 12. 09.]

Syria’s drained population: Syria’s depleted and war-torn population, [online], 2015. 09. 30. Forrás: economist. com [2019. 11. 19.]

Tsourapas, Gerasimos: The Syrian Refugee Crisis and Foreign Policy Decision-Making in Jordan, Lebanon, and Turkey, Journal of Global Security Studies, 4. évf., 2019/4, 464-481. o. DOI: https://doi.org/10.1093/jogss/ogz016 Vulnerability Assessment of Syrian Refugees in Lebanon, [online], 2018. Forrás: unhcr.org [2019. 12. 04.] 
VelazQuez, Felipe Cuamea: Approaches to the study of international migration: a review, Estudios Fronterizos, 1. évf., 2000/1, 137-168. o. DOI: https://doi.org/10.21670/ref.2000.01.a04

Vohra, Anchal: Lebanon Is Sick and Tired of Syrian Refugees, [online], 2019. 07. 31. Forrás: foreignpolicy. com [2019. 12.08.]

What is a refugee? [online], Forrás: unhcr.org [2019. 11. 16.]

Where we work: Lebanon, [online], Forrás: unrwa.org [2019. 12. 04.]

Why are returns of refugees from Lebanon to Syria premature?, [online], 2019. 06. 12. Forrás: amnesty.org [2019. 12. 08.]

Yee, Vivian: In Lebanon Town, Refugees and Locals Agree on 1 Thing: Time for Syrians to Go, [online], 2018. 08. 08. Forrás: nytimes.com [2019. 12.04.] 